\title{
A Transgenic Lettuce Line with Resistance to Both Lettuce Big-vein Associated Virus and Mirafiori Lettuce Virus
}

\author{
Yoichi Kawazu ${ }^{1}$ and Ryoi Fujiyama \\ National Institute of Vegetable and Tea Science, Ano, Mie, 514-2392, Japan \\ Keita Sugiyama \\ National Agricultural Research Center for Hokkaido Region, Sapporo, Hokkaido, 062-8555, Japan \\ Takahide Sasaya \\ Policy Planning and Evaluation Division, the Ministry of Agriculture, Forestry and Fisheries of Japan, \\ Kasumigaseki, Tokyo, 100-8950, Japan
}

\begin{abstract}
Additional INDEX words. LBVaV, MiLV, coat protein (CP) gene, virus resistance, Lactuca sativa
ABstract. The coat protein (CP) gene of lettuce big-vein associated virus (LBVaV) in sense or antisense orientation in a binary vector $\mathrm{pBI} 121$ was transformed via Agrobacterium tumefaciens (Smith and Towns.) Conn. mediated transformation into lettuce (Lactuca sativa $\mathrm{L}$.) to generate $\mathrm{LBVaV}$-resistant lettuce. Nineteen $\mathrm{T}_{1}$ lines were produced; five to 10 plants of each $\mathrm{T}_{1}$ line were inoculated with LBVaV using Olpidium brassicae (Wor.) Dang.; and LBVaV was not detected in eight plants derived from six lines. $T_{2}$ seedlings from the eight plants were tested for $\mathrm{LBVaV}$ resistance, and one line (line A-2) with the CP gene in antisense orientation was resistant to LBVaV while the other lines were susceptible. The transgenic line A-2 was also resistant to mirafiori lettuce virus (MiLV) and big-vein expressions regardless of the presence or absence of LBVaV.
\end{abstract}

Lettuce big-vein disease, first described in California (Jagger and Chandler, 1934), is a soilborne disease transmitted by the fungus Olpidium brassicae (Campbell and Grogan, 1964). Infected lettuce plants develop vein bandings, and leaves become ruffled and distorted. A virus with rod-shaped particles, named lettuce big-vein associated virus (Fauquet et al., 2005), previously named lettuce big-vein virus, was first found in lettuce with big-vein disease (Kuwata et al., 1983); this virus was believed to be a causal agent of big-vein disease for nearly two decades. However, a second virus, named mirafiori lettuce virus, was recently isolated from lettuce showing big-vein symptoms (Roggero et al., 2000), and it was reported that MiLV but not LBVaV induced big-vein symptoms in lettuce (Lot et al., 2002). Although $\mathrm{LBVaV}$ is not regarded as a causal agent of big-vein disease, it is possible that $\mathrm{LBVaV}$ is related to MiLV infections and big-vein symptom expressions because $\mathrm{LBVaV}$ is frequently associated with big-vein disease.

One of the most efficient methods to control big-vein disease is the use of resistant cultivars (Ryder and Robinson, 1995). Resistant cultivars have been developed by a conventional breeding method. For example, the big-vein-resistant cultivars Thompson and Pacific were developed using several resistant sources (Ryder, 1981; Ryder and Robinson, 1991). However, cultivars released so far do not exhibit high levels of resistance because breeding sources with high resistance to the disease have not been found in lettuce (Bos and Huijberts, 1990; Ryder and Robinson, 1995).

Received for publication 12 Jan. 2006. Accepted for publication 21 June 2006. Acknowledgments. We thank Dr. Masayasu Nagata for help with the construction of pYK10 and pYK11. We also thank Dr. Hiroki Koganezawa for providing $O$. brassicae carrying MiLV alone.

'Corresponding author: e-mail: ykawazu@affrc.go.jp; phone: +81-59-268-4650; fax: +81-59-268-1339.
It was suggested that the expression of viral gene sequences in transgenic plants might disrupt the viral life cycle (Sanford and Johnston, 1985), and virus-derived resistance in transgenic plants was first reported using the CP gene of tobacco mosaic virus (Powell-Abel et al., 1986). After these reports, there have been numerous attempts to generate virus resistance in transgenic plants through the expression of CP genes, viral replicase genes, and other viral sequences (Baulcombe, 1996). Many of these attempts have been successful, and the use of viral sequences to produce virus-resistant plants is now routine.

Nucleotide sequences of LBVaV and MiLV were recently reported (Kawazu et al., 2003; Sasaya et al., 2002, 2004; van der Wilk et al., 2002), and it is now possible to transform lettuce with $\mathrm{LBVaV}$ or MiLV sequences to produce transgenic lettuce with resistance to LBVaV or MiLV. In this study we introduced the LBVaV CP gene into lettuce to make LBVaV-resistant lettuce, and a transgenic lettuce line was obtained that was resistant not only to LBVaV but also to MiLV, and therefore repressed symptom expressions.

\section{Materials and Methods}

Transformation of lettuce with the LBVaV CP gene. The $\beta$-glucuronidase (GUS) gene in pBI121 was replaced by the full coding sequence of the LBVaV CP gene $(1.2 \mathrm{~kb})$, and the plasmids with the LBVaV CP gene in antisense and sense orientations were referred to as pYK10 and pYK11, respectively. The binary vector pYK10 or pYK11 was transformed via $A$. tumefaciens-mediated transformation into 'Cisco' lettuce by the leaf disc method (Curtis et al., 1995). Explants were regenerated on medium containing $100 \mathrm{mg} \cdot \mathrm{L}^{-1}$ kanamycin. PCR was carried out to detect the LBVaV CP gene in transgenic plants using the following primers: 5'-GATGT GATATCTCCACTGACGTAAG- 
3'(CaMV 35S promoter region) and 5'-CTCATAAATAACGTC ATGCA TTACA-3' (NOS terminator region).

ViRUS INOCULATION AND DETECTION. Olpidium brassicae was obtained from lettuce showing big-vein symptoms in Kagawa prefecture, Japan. It was confirmed to contain both LBVaV and MiLV when they were detected using Western blot analysis and double-antibody sandwich enzyme-linked immunosorbent assay (DAS-ELISA) in susceptible 'Cisco' plants $60 \mathrm{~d}$ after inoculation. The methods for virus detection are described below. Olpidium brassicae carrying MiLV alone was kindly provided by Dr. $\mathrm{H}$. Koganezawa (Kaneko Seeds Co., Gunma, Japan). Olpidium brassicae were maintained in 'Cisco' plants and determined to be viruliferous when inoculated plants showed big-vein symptoms. Roots of 'Cisco'plants infected with $O$. brassicae containing both viruses or MiLV alone were used for inoculation. Five grams of roots were homogenized with $300 \mathrm{~mL}$ of deionized water using a juicer. They were then filtrated with one-layer gauze, and $10 \mathrm{~mL}$ of homogenized roots were poured onto the base of each seedling. Inoculated plants were kept in a plant growth chamber at $20^{\circ} \mathrm{C}$ during the day (14-h photoperiod) and at $15^{\circ} \mathrm{C}$ at night. Two discs were punched from randomly selected leaves of each lettuce plant using the lid of a $2-\mathrm{mL}$ microfuge tube. Each lettuce sample was disrupted with $0.4 \mathrm{~mL}$ of PBS-T (20 mm Na-phosphate buffer, $\mathrm{pH}$ $7.2,150 \mathrm{~mm} \mathrm{NaCl}, 0.05 \%$ Tween-20) and centrifuged with 6700 $g_{\mathrm{n}}$ for $1 \mathrm{~min}$. The supernatant was used for Western blot analysis to detect LBVaV and for DAS-ELISA to detect MiLV.

Protein extract $(10 \mu \mathrm{L})$ was subjected to $10 \%$ SDS-polyacrylamide gel electrophoresis, and Western blot analysis for detection of LBVaV was conducted according to a standard procedure (Gallagher et al., 1993). Mouse antiserum against LBVaV diluted 1:3000 was used for the primary antibody, and the alkaline phosphatase-conjugated goat antibody (Bio-Rad Laboratories, Hercules, Calif.) diluted 1:10,000 was used for the secondary antibody. A sample was considered LBVaV-positive if the CP band was observed on X-ray film.

DAS-ELISA for detection of MiLV was performed essentially as described by Clark and Adams (1977). The antibody for coating and the antibody-alkaline phosphatase (AP) conjugate (Japan Plant Protection Association Corp., Tokyo) were diluted 1:500 and $1: 1500$, respectively. One milligram per milliliter p-nitrophenyl phosphate (NPP) was finally added into wells of microtiter plates and incubated at $37{ }^{\circ} \mathrm{C}$ for $70 \mathrm{~min}$. A sample was considered MiLV-positive if the difference of the absorbance at $405 \mathrm{~nm}$ between the sample and uninoculated controls was more than 0.1.

Southern HYBRIDIZATION. Genomic DNA was isolated from lettuce leaves by the CTAB method as described by Roger and Bendich (1988). Approximately $10 \mu \mathrm{g}$ of genomic DNA was digested with Eco RI, Eco RV or Hind III, and the resulting fragments were electrophoresed in $1.5 \%$ agarose gel and transferred to a Hybond-N+ membrane (GE Healthcare Bio-Sciences Corp., Piscataway, N.J.) by capillary blotting (Sambrook and Russell, 2001). The full coding sequence of the LBVaV CP gene $(1.2 \mathrm{~kb})$ or the $n p t$ II gene $(0.8 \mathrm{~kb})$ was labeled with an alkaline phosphatase using the AlkPhos Direct Labelling and Detection System (GE Healthcare Bio-Sciences). The hybridization was performed according to the manufacturer's recommendations.

\section{Results and Discussion}

Production of transgenic lettuce. In order to produce transgenic lettuce, 6200 leaf segments were inoculated with $A$. tumefaciens carrying the LBVaV CP gene in antisense orientation on the binary plasmid pYK10, and 30 independent plant lines $\left(\mathrm{T}_{0}\right.$ generation) were regenerated on medium containing $100 \mathrm{mg} \cdot \mathrm{L}^{-1}$ kanamycin. Seventeen of 30 plants were shown to be CP genepositive by PCR analysis (data not shown), and self-pollinated. Seven of 17 plants produced seeds ( $\mathrm{T}_{1}$ generation) while 10 plants did not produce seeds or died before flowering.

Another 6200 leaf segments were inoculated with A. tumefaciens carrying the LBVaV CP gene in sense orientation on the binary plasmid pYK11, and 36 independent plant lines were regenerated on medium containing $100 \mathrm{mg} \cdot \mathrm{L}^{-1}$ kanamycin. Twenty-two of 36 plants were shown to be $\mathrm{CP}$ gene-positive by PCR analysis (data not shown), and 12 of 22 plants produced seeds $\left(\mathrm{T}_{1}\right.$ generation) while 10 plants did not produce seeds or died before flowering.

Selection of transgenic plants for LBVaV resistance. In order to screen resistant lines, five to 10 plants of each $T_{1}$ line (seven lines with the LBVaV CP gene in antisense orientation and 12 lines with the LBVaV CP gene in sense orientation) were inoculated with $\mathrm{LBVaV}$ using $O$. brassicae. $\mathrm{LBVaV}$ was detected using Western blot analysis. Five plants from three lines with the LBVaV CP gene in antisense orientation and three plants from three lines with the LBVaV CP gene in sense orientation were LBVaV-negative $56 \mathrm{~d}$ after inoculation (data not shown), and they were self-pollinated for resistance test in $\mathrm{T}_{2}$ generation. All plants of line A-2 were $\mathrm{LBVaV}$-negative while almost all plants of the other lines were LBVaV-positive $31 \mathrm{~d}$ after inoculation (Table 1). The presence of the $\mathrm{CP}$ gene in line $\mathrm{A}-2$ was checked by PCR analysis, and all plants tested were CP gene-positive (Data not shown). Southern blot analysis was also performed on genomic DNA from eight plants of line A-2 (Fig. 1). The result shows the presence of one copy of the LBVaV CP gene (Panel $\mathrm{B}$ ) and one copy of the $n p t$ II gene (Panel C) per genome. Two bands were detected when genomic DNA digested with Eco RI was hybridized with the LBVaV CP probe because of the presence of the Eco RI site in the LBVaV CP gene (Lane 1 in Panel B).

Analysis of transGenic line A-2. We examined the resistance of line A-2 not only to LBVaV but also to MiLV and symptom expressions (Figs. 2-3). All lineA-2 plants were LBVaV-negative, MiLV-negative, and without symptoms while all 'Cisco' plants were LBVaV-positive, MiLV-positive and symptomatic $40 \mathrm{~d}$ after inoculation. We saw no significant difference in growth between line A-2 and 'Cisco' plants. As line A-2 has the LBVaV CP gene in antisense orientation, the transgene is untranslatable, suggest-

Table 1. Percentages of lettuce big-vein associated virus (LBVaV)-positive lettuce plants of $\mathrm{T}_{2}$ generation inoculated with $\mathrm{LBVaV}$ using Olpidium brasicae.

\begin{tabular}{lcc}
\hline Line & $\begin{array}{c}\text { Orientation of } \\
\text { the coat protein gene }\end{array}$ & LBVaV-positivey \\
\hline A-1 & antisense & $94 \%(15 / 16)$ \\
A-2 & antisense & $0 \%(0 / 16)$ \\
A-3 & antisense & $81 \%(13 / 16)$ \\
E-1 & antisense & $100 \%(16 / 16)$ \\
G-1 & antisense & $100 \%(16 / 16)$ \\
H-1 & sense & $100 \%(16 / 16)$ \\
M-1 & sense & $100 \%(16 / 16)$ \\
N-1 & sense & $100 \%(16 / 16)$ \\
Cisco (control) & & $100 \%(8 / 8)$
\end{tabular}

${ }^{2}$ Each lettuce line represents the progeny of selected plants of $\mathrm{T}_{1}$ generation. 'Cisco' is the parental non-transformed cultivar.

ySamples were collected from lettuce leaves $31 \mathrm{~d}$ after inoculation. LBVaV positive/total number of plants tested is indicated in parentheses. 
(A)
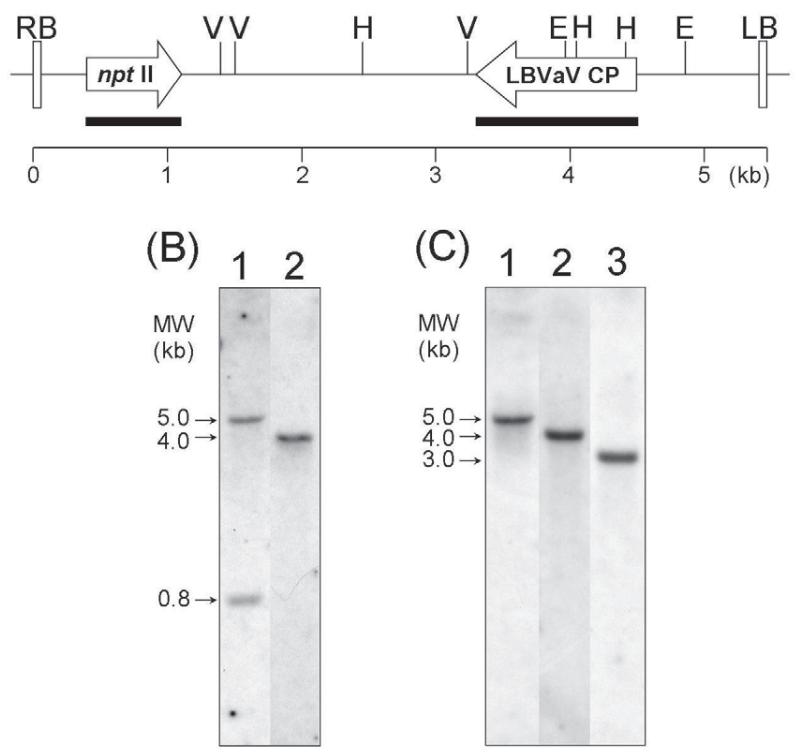

Fig. 1. Southern blot analysis of the transgenic lettuce line A-2 to determine the transgene copy number. (A) A map of the transferred DNA (T-DNA) region of pYK10. Solid lines, DNA probes; RB = T-DNA right border; LB = T-DNA left border; $n p t$ II $=n p t$ II gene; $\mathrm{LBVaV} \mathrm{CP}=$ the coat protein $(\mathrm{CP})$ gene of lettuce big-vein associated virus $(\mathrm{LBVaV}) ; \mathrm{E}=E$ co $\mathrm{RI}$ site; $\mathrm{V}=E$ co $\mathrm{RV}$ site; $\mathrm{H}=$ Hind III site. Genomic DNA of line A-2 was digested with Eco RI (lane 1), Eco RV (lane 2) or Hind III (lane 3), and hybridized with the LBVaV CP probe (B) or the $n p t$ II probe $(\mathbf{C})$. MW = molecular weight. The figure shows the result from one plant, but the same result was obtained from the other seven plants. ing that the resistance to $\mathrm{LBVaV}$ in line A-2 is RNA-mediated. Detection of mRNA from LBVaV CP gene has not been successful while mRNA from $n p t$ II gene was detected by Northern blot analysis (data not shown). It is possible that the failure of the detection is due to RNA silencing of the LBVaV CP gene in line A-2. On the other hand, the resistance of line A-2 to MiLV was unexpected because RNA-mediated resistance is only effective against viruses with a high degree of sequence homology to transgenes (van den Boogaart et al., 1998). LBVaV and MiLV are different species (the genera Varicosavirus and Ophiovirus, respectively) (Fauquet et al., 2005), and we can see no significant sequence similarity between them. MiLV infection was possibly inhibited in line A-2 as a result of gene silencing for LBVaV if MiLV infection was helped by LBVaV. In order to make it clear whether the inhibition of MiLV infection in line A-2 was due to the inhibition of LBVaV infection, line A-2 plants were inoculated with $O$. brassicae carrying MiLV alone (Fig. 4). Fifty-three and $80 \mathrm{~d}$ after inoculation, all 'Cisco' plants were LBVaV-negative, MiLV-positive and symptomatic, which is consistent with the previous report that MiLV but not $\mathrm{LBVaV}$ induced big-vein symptoms in lettuce (Lot et al., 2002). On the other hand, all line A-2 plants were MiLV-negative and without symptoms, indicating that line A-2 is resistant to MiLV regardless of the presence or absence of LBVaV. Further experiments are required to clarify the resistance mechanism to MiLV in line A-2.

The resistant cultivar Pacific was released about 20 years ago (Ryder and Robinson, 1991), but no cultivar with higher resistance has been released because new resistant breeding sources
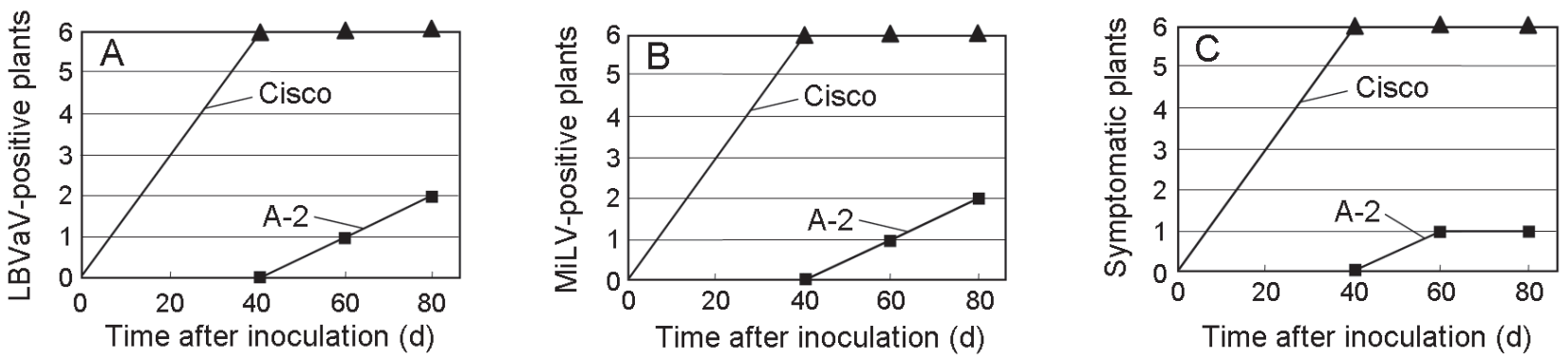

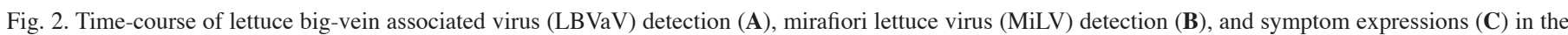
transgenic lettuce line A-2 plants and the non-transformed 'Cisco' lettuce plants. Six line A-2 plants and six 'Cisco' plants were inoculated with LBVaV and MiLV using Olpidium brassicae, and the numbers of LBVaV-positive, MiLV-positive or symptomatic plants were counted. LBVaV and MiLV were detected using Western blot analysis, and double-antibody sandwich enzyme-linked immunosorbent assay (DAS-ELISA), respectively. Plants were regarded as symptomatic when vein bandings were observed at least on one leaf.
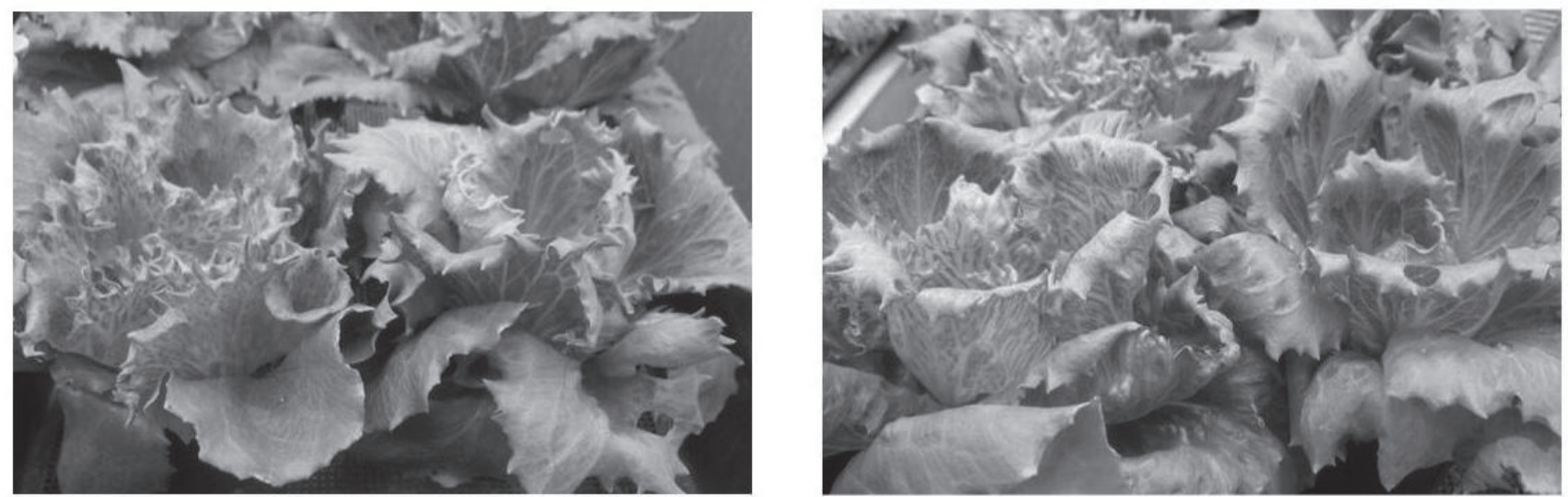

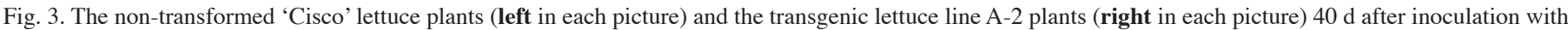
lettuce big-vein associated virus (LBVaV) and mirafiori lettuce virus (MiLV) using Olpidium brassicae. 

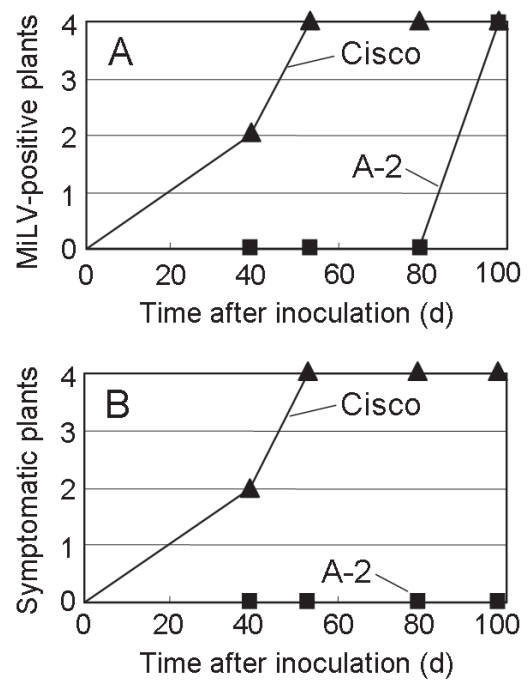

Fig. 4. Time-course of mirafiori lettuce virus (MiLV) detection (A) and symptom expressions (B) in the transgenic lettuce line A-2 plants and the non-transformed 'Cisco' lettuce plants after inoculation with MiLV alone using Olpidium brassicae. Four line A-2 plants and four 'Cisco' plants were inoculated, and the numbers of MiLV-positive or symptomatic plants were counted. Lettuce big-vein associated virus ( $\mathrm{LBVaV}$ ) and MiLV were detected using Western blot analysis and double-antibody sandwich enzyme-linked immunosorbent assay (DAS-ELISA), respectively. Plants were regarded as symptomatic when vein bandings were observed at least on one leaf. All plants were LBVaV-negative at any time tested.

have not been found in lettuce. The production of transgenic plants with virus-derived nucleotides is therefore an attractive alternative method. In this study we obtained transgenic lettuce with resistance to big-vein using the LBVaV CP gene. It is possible to use this transgenic lettuce as a resistant cultivar or as a breeding source.

\section{Literature Cited}

Baulcombe, D.C. 1996. Mechanisms of pathogen-derived resistance to viruses in transgenic plants. Plant Cell 8:1833-1844.

Bos, L. and N. Huijberts. 1990. Screening for resistance to big-vein disease of lettuce (Lactuca sativa). Crop Protection 9:446-452.

Campbel, R.N. and R.G. Grogan. 1964. Acquisition and transmission of lettuce big-vein virus by Olpidium brassicae. Phytopathology 54:681-690.

Clark, M.F. and A.N. Adams. 1977. Characteristics of the microplate method of enzyme-linked immunosorbent assay for the detection of plant viruses. J. Gen. Virol. 34:475-483.

Curtis, I.S., M.R. Davey, and J.B. Power. 1995. Leaf disk transformation, p. 59-70. In: K.M.A. Gartland and M.R. Davey (eds.). Methods in molecular biology 44 (Agrobacterium protocols). Humana Press, Totowa, N.J.

Fauquet, C.M., M.A. Mayo, J. Maniloff, U. Desselberger, and L.A. Ball (eds.). 2005. Virus taxonomy: Eighth report of the International
Committee on the Taxonomy of Viruses. Elsevier Academic Press, San Diego.

Gallagher, S., S.E. Winston, S.A. Fuller, and J.G.R. Hurrell. 1993. Immunoblotting and immunodetection, UNIT 10.8.1-10.8.17. In: F.M. Ausubel, R. Brent, R.E. Kingston, D.D. Moore, J.G. Seidman, J.A. Smith, and K. Struhl (eds.). Current protocols in molecular biology. Current Protocols, New York.

Jagger, I.C. and N. Chandler. 1934. Big vein, a disease of lettuce. Phytopathology 24:1253-1256.

Kawazu, Y., T. Sasaya, T. Morikawa, K. Sugiyama, and T. Natsuaki. 2003. Nucleotide sequence of the coat protein gene of mirafiori lettuce virus. J. Gen. Plant Pathol. 69:55-60.

Kuwata, S., S. Kubo, S. Yamashita, and Y. Doi. 1983. Rod-shaped particles, a probable entity of lettuce big vein virus. Ann. Phytopathol. Soc. Jpn. 49:246-251.

Lot, H., R.N. Campbell, S. Souche, R.G. Milne, and P. Roggero. 2002. Transmission by Olpidium brassicae of mirafiori lettuce virus and lettuce big-vein virus, and their roles in lettuce big-vein etiology. Phytopathology 92:288-293.

Powell-Abel, P., R.S. Nelson, B. De, N. Hoffmann, S.G. Rogers, R.T. Fraley, and R.N. Beachy. 1986. Delay of disease development in transgenic plants that express the tobacco mosaic virus coat protein gene. Science 232:738-743.

Roger, S.O. and A.J. Bendich. 1988. Extraction of DNA from plant tissues, A6.1-A6.10. In: S.B. Gelvin, R.A. Schilperoort, andD.P.S. Verma (eds.). Plant molecular biology manual. Kluwer Academic Publishers, Dordrecht, The Netherlands.

Roggero, P., M. Ciuffo, A.M. Vaira, G.P. Accotto, V. Masenga, and R.G. Milne. 2000. An Ophiovirus isolated from lettuce with big-vein symptoms. Arch. Virol. 145:2629-2642.

Ryder, E.J. 1981. 'Thompson' lettuce. HortScience 16:687-688.

Ryder, E.J. and B.J. Robinson. 1991. 'Pacific' lettuce. HortScience 26:437-438.

Ryder, E.J. and B.J. Robinson. 1995. Big-vein resistance in lettuce: Identifying, selecting, and testing resistant cultivars and breeding lines. J. Amer. Soc. Hort. Sci. 120:741-746.

Sambrook, J. and D.W. Russell. 2001. Molecular cloning. A laboratory manual, 3rd ed. Cold Spring Harbor Laboratory Press, Cold Spring Harbor, N.Y.

Sanford, J.C. and S.A. Johnston. 1985. The concept of parasite-derived resistance-deriving resistance genes from the parasite's own genome. J. Theor. Biol. 113:395-405.

Sasaya, T., K. Ishikawa, and H. Koganezawa 2002. The nucleotide sequence of RNA1 of lettuce big-vein virus, genus Varicosavirus, reveals its relation to nonsegmented negative-strand RNA viruses. Virology 297:289-297.

Sasaya, T., S. Kusaba, K. Ishikawa, and H. Koganezawa. 2004. Nucleotide sequence of RNA2 of lettuce big-vein virus and evidence for a possible transcription termination/initiation strategy similar to that of rhabdoviruses. J. Gen. Virol. 85:2709-2717.

van den Boogaart, T., G.P. Lomonossoff, and J.W. Davies. 1998. Can we explain RNA-mediated virus resistance by homology-dependent gene silencing? Mol. Plant-Microbe Interaction 11:717-723.

van der Wilk, F., A.M. Dullemans, M. Verbeek, and J.F. van den Heuvel. 2002. Nucleotide sequence and genomic organization of an ophiovirus associated with lettuce big-vein disease. J. Gen. Virol. 83:2869-2877. 